\title{
Application of Estriol in Gynecological Field (Second Report)
}

Some Effects of Estriol on Excretion of Various Hormones in the Urine and on Vaginal Smears

\section{Shimpei TOJO, Michizo MIKI, Yukio MANABE, \& Kinya INOUE}

Department of Obstetrics and Gynecology, Kyoto University School of Medicine

(Director : Prof. Ryukichi Mibayashi, M.D.)

Estriol was given orally to oophorectomized women and estimations were made of the excretion of the various hormones in the urine. The results were as follows:

There was a fall in the urinary output of gonadotropins, while there was a rise of the individual estrogens (estriol, estron and estradiol) and of total neutral 17-Ketosteroids. Consequently, we assumed that estriol has the suppressing action on the pituitary, on the other hand it has the activating action on the adrenal cortex. 


\title{
婦人科領域に於ける Estriol の応用
}

\author{
（第 2 報） Estriol 投与が尿中諸種ホルモン排泄量並びに \\ 腔脂膏に及ぼす影響
}

$$
\begin{array}{r}
\text { 京都大学医学部産婦人科教室（主任 三林隆吉教授） } \\
\text { 東 條 伸 平, 真 鍋 幸 夫 } \\
\text { 三木 通 三，井 上 欣 也 }
\end{array}
$$

（昭和36年 4 月10日受付）

緒言

Estriol は Estrogene の終末代謝産物と見做され，その生物学的作用に関しては従来等閉視されて来た感

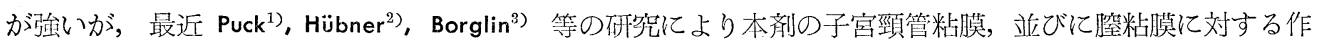
用が注目されてから，その内分泌学的意義が改めて見直されるようになり, Estriol の性器作用, 性器外作 用に関する知見も続々と集成されつつある。

著者等は以前から女性性週期異常に関する知見の拡大に努力しているが，その研究の一端として Estriol の性機能に対する影響をも併せて検索中であり，既に第 1 報) 亿於して主として更年期障碍，月経前緊張症， 並びに月経团難症に本剂を投与せる際の臨床成績を発表したが，今回は第 2 報として，Estriol が婦人の内 分泌環境に及ぼす影響を分析すべく，Estriol 投与前後の尿中諸種ホルモンの推移を系統的に追求し，併せ て腟脂旁に及ぼす作用を調べた成績を報告する。

\section{I 実験対象並びに方法}

実験対象は, 京都大学医学部産婦人科学教室に於いて, 子宮癌根治手術を受けた去勢婦人 5 例（30才〜62 才）であり，何れも術後15日目より Estriol 1 日300 rを経口的に 7 日間連続投与し，投与開始の前日，投 与終了の翌日，並びに終了後 7 日目の尿につき Hormone assay を行い，また同時期の膣脂高を検討した. 角化指数の検索には更年期障碍の婦人 2 例を加えてある.

なお投与開始の時期を術後15日目としたのは, 子宮癌根治手術の侵襲による Hormone milieu の变動は術 後 2 週間でほぼ解消してしまうてとが知られておるからであり，また投与形式を経口的としたのは Hohlweg ${ }^{5)}$ 等の実験により, Estriol は経口的に与えても, 非経口的に与えても生物学的作用に殆んど差のないととが わかつているから，投与方法の簡単なものを選んだわけである.

\section{A) Hormone-assay の方法}

$1^{\circ}$ Gonadotropin

Evans の方法に準じて我々が以前から行つている幼若マウス子宮重量法を採用した ${ }^{13)}$.

$2^{\circ}$ Estrogen

Brown-志田の方法により Estradiol, Estrone, Estriol の 3 分劃を測定した ${ }^{15}$.

$3^{\circ}$ 17-Ketosteroid

三宅氏法に準ずる教室の谷の方法によつた ${ }^{14)}$.

$4^{\circ}$ 17-Hydroxycorticosteroid 
Reddy 氏変法に準ずる教室の谷の方法に よつた ${ }^{14)}$.

\section{B）腔脂高の祫討}

腔脂哣を Schorr の方法により染色検鏡 し，その角化指数を算定した.

\section{II 実 験 成 績}

先づ Gonadotropin の推移を見ると，第 1 表の如く，Estriol 投与終了渵後には 5 例 中 4 例（No. I, II, IV, V) では明らかに
第 1 表 尿中 Gonadotropin (M.U.U/day.)

\begin{tabular}{c|c|c|c|c}
\hline No. & 年令 & 投与 前 & 投与終了直後 & $\begin{array}{c}\text { 投与終了 } \\
\text { 1 週 }\end{array}$ \\
\hline I & 38 & 32 間 \\
II & 53 & $16 \sim 32$ & 5 以下 & $5 \sim 10$ \\
III & 62 & $20 \sim 40$ & $6 \sim 12$ & $?$ \\
IV & 40 & $32 \sim 64$ & 13 - 26 & $30 \sim 60$ \\
V & 30 & $25 \sim 50$ & $4 \sim 8$ & $10 \sim 20$ \\
\hline
\end{tabular}

注〜は検定の巾を示す

第 1 図尿中 Gonadotropin の推移
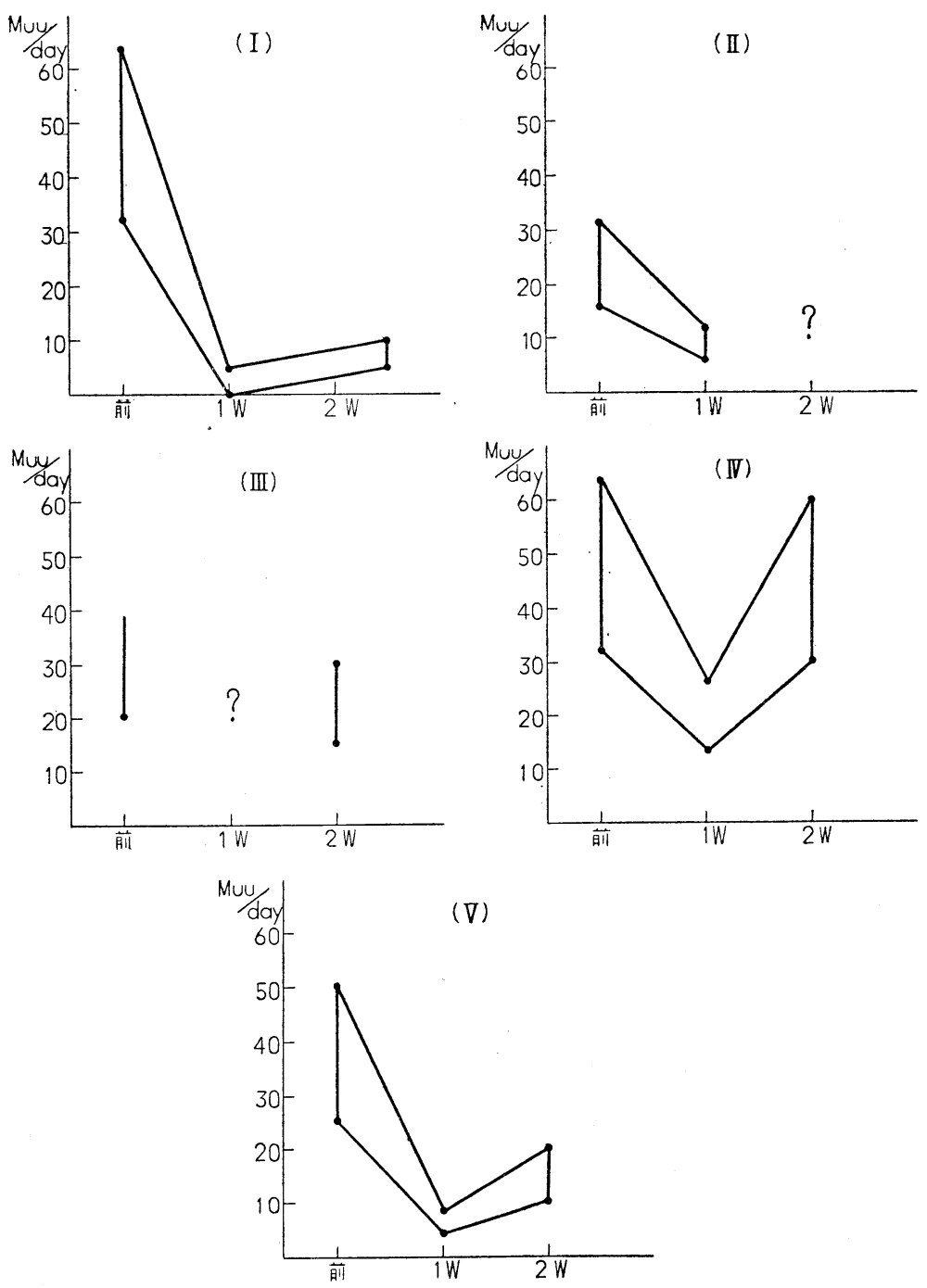

第37巻 第 4 号 
減少しており, 最後まで追求し得た 3 例（No. I， N， V) では投与終了後 1 週間して，やや増加の傾向を 示している. その推移は一括して第1図㐾してある.

次に尿中 Estrogene の推移を第 2 表, 第 2 図に示す．即ち Estriol 分画は投与終了直後 には全例共に増しており，内 3 例（No. I， II，V）は投与終了後 1 週間目には，ほぼ旧 值乃至それ以下に減少するが，他の 2 例 （No. III，IV）は投与前よりも高值を維持し ている.

Estradiol 分画を見ると, Estriol 投与終了 直後には增すものが多く，5例中 4 例（No.

II， II， IV，V）で増加しているが，1 週間 後にはほぼ旧值に戻つている。

Estrone 分画も，“投与終了直後に一過性に やや増すものが多い. (No. I, II, III)

17-Ketosteroid の推移は第 3 表, 第 3 図に 示す如く特異的であり, Estriol 投与終了直 後には 5 例中 4 例 (No. II, III, IV, V) で 明らかに増加しており，1週間後には全例著 しい低值となつている。

これに反し，17-Hydroxycorticosteroid は投与終了直後一過性にやや増したものは 2 例に過ぎず一般に大きな変動を示さない.

第 2 表 Estorogen 三分劃 $(\mu \mathrm{g} / \mathrm{day})$

\begin{tabular}{c|c|r|r|r}
\hline \multirow{2}{*}{ No. } & & 投与前 & \multicolumn{2}{|c|}{$\begin{array}{c}\text { 投与終投与描了 } \\
\text { 終 }\end{array}$} \\
\hline \hline \multirow{3}{*}{ I } & Estradiol & 11.7 & 7.7 & 12.0 \\
& Estron & 13.5 & 16.5 & 16.0 \\
& Estriol & 18.7 & 18.8 & 14.7 \\
\hline \multirow{3}{*}{ II } & Estradiol & 13.5 & 14.7 & 17.3 \\
& Estron & 9.5 & 15.7 & 12.3 \\
& Estriol & 14.8 & 15.1 & 8.9 \\
\hline \multirow{3}{*}{ II } & Estradiol & 8.1 & 17.3 & 7.2 \\
& Estron & 12.1 & 14.4 & 17.3 \\
& Estriol & 14.7 & 25.3 & 21.6 \\
\hline \multirow{3}{*}{ IV } & Estradiol & 14.0 & 19.5 & 9.3 \\
& Estron & 12.1 & 11.2 & 8.4 \\
& Estriol & 8.1 & 8.8 & 12.0 \\
\hline \multirow{3}{*}{ V } & Estradiol & 13.5 & 27.1 & 17.6 \\
& Estron & 10.7 & 9.6 & 12.1 \\
& Estriol & 11.1 & 14.0 & 11.3 \\
\hline
\end{tabular}

腔脂高の角化指数の推移は第 5 表, 第 5 図の如く，何れも投与終了直後には増加しているが，投与終了後 1 週間目にはやや減少の傾向を示している.

以上の成績を簡単にまとめてみると，Estriol 投与により，尿中 Gonadotropin は一過性に減少するのに 反し, Estrogene をみると, Estrsol 分画は勿論の事, 所譄 biologically active な, Estradiol 分画, Estrone 分画も共に増すものが多く，17-Ketosteroid もほぼてれと轨を一にして推移しており，㓐脂高の角化指数も てれと並行して変化することがわかつた。

てれに反し 17-Hydroxycorticosteroid には特異的な変動は認められなかつた。

\section{III 考按}

生体内での Estrogene の代謝機構に関しては今日多くの研究がなされており，17- $\beta$-Estrodiol, Estrone 等の所謂 biological activity の高い Estrogene が生体内で Estriol に転換されると云う経路は一般に認め られているとてろであるが，Estriol から逆に前二者へ移行する経路は全く否定的である.

その代謝経路を模型的に示せば下記の如くなる.(Schnitte ${ }^{6)}$ )

即ち Estriol はあくまでも Estrogene の終末代謝産物であると見做され，その生物学的作用も問題視さ れていなかつたのであるが，最近諸家により Estriol の生物学的作用が再認識され，著者等も婦人科領域に おける代表的な内分泌疾患と云える更年期障碍, 月経前緊張症, 月経困難症等に Estriol を投与して, 臨床 上認むべき効果を得，第 1 報に於いて，Estriol が何故てのような症候群に対して治療効果を発揮するが ついて，一応の内分泌学的考察を試みておいた。

今回は更に実験の第二段階として，Estriol が内分泌環境に及ぼす影響を，尿中 Hormone の Assay の 面から分析してみたわけであるが，先づ，去勢婦人に Estriol を1日300r，7 日間連続投与すると，投与 
第 2 図 Estrogen 3 分劃の推移
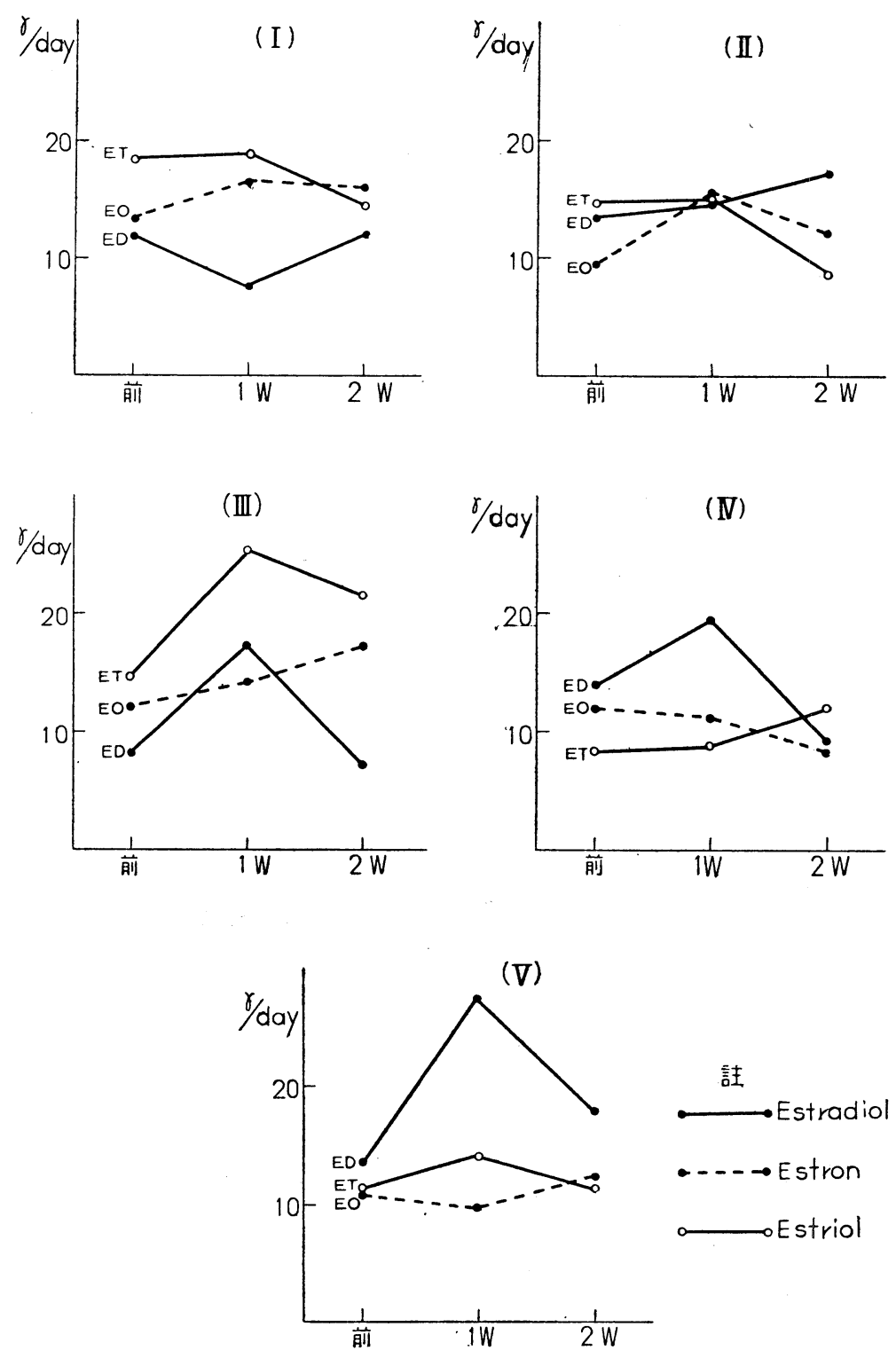

...終了直後に尿中 Gonadotropin の著減する例が多いととを知つた. 從来 Estrogene 特に Estradiol, Estrone が間脳を介して下垂体前葉よりの Gaondotropin 分必を抑制するてとは動物実験によつても，また臨床実 験によつても一般に認められた事実であるが (Moore \& Price ${ }^{7)}$ 1930, Meyer et al ${ }^{8}$ 1930, 1932, Frankle \& Salmon'9 1935, 等々), Estriol の単独投与により去勢婦人の尿中 Gonadotropin が減少したてとは, Estradiol, Estrone 同様，Estriol にも，上位を介して下垂体前葉よりの Gonadotropin 分泌を抑制する作用があ ることを暗示するものであろう。

次に Estriol 投与前後の尿中 Estrogene の各分画の推移を見ると, Estriol 投与後に, Estriol 分画が増 第37巻 第 4 号 
第 3 表 17-Ketosteroid (mg/day)

\begin{tabular}{c|r|r|c}
\hline No. & 投 与 前 & 投与終了直後 & $\begin{array}{c}\text { 投与終了 } \\
\text { 1 週 }\end{array}$ \\
\hline \hline I & 13.44 & 8.38 & 4.26 \\
II & 11.37 & 13.57 & 2.46 \\
III & 8.09 & 15.04 & 4.35 \\
IV & 10.26 & 13.60 & 4.93 \\
V & 4.46 & 8.82 & 2.75 \\
\hline
\end{tabular}

第3 図 17Ketosteroid の推移

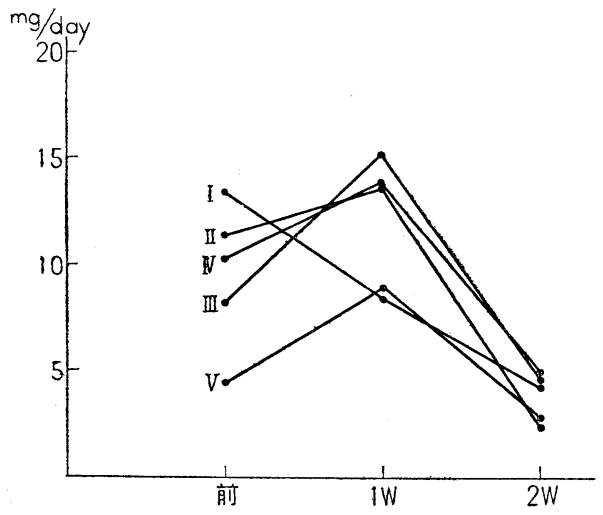

第 4 表 17-OHCorticostroid (mg/day)

\begin{tabular}{c|c|c|c}
\hline No. & 投与 前 & 投与終了直後 & $\begin{array}{c}\text { 投与終了 } \\
1\end{array}$ 週後 \\
\hline \hline I & 1.94 & 11.29 & 1.94 \\
II & 6.46 & 1.81 & 1.00 \\
II & 1.90 & 3.29 & 3.57 \\
IV & 3.74 & 1.55 & 2.57 \\
V & 2.97 & 1.35 & 0.61 \\
\hline
\end{tabular}

第 4 図 17OHCorticosteroid の推移

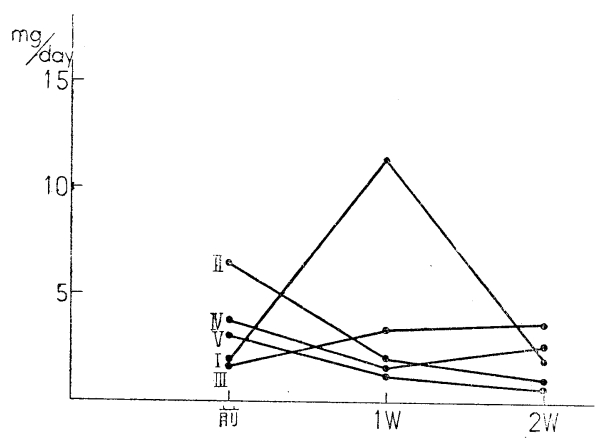

第 5 表 腔脂蹇角化係数 $(\%)$

\begin{tabular}{|c|c|c|c|c|c|}
\hline No. & 症 & 例 & 投与前 & $\begin{array}{c}\text { 投与絶 } \\
\text { 了直後 }\end{array}$ & $\begin{array}{l}\mid f 殳^{\prime} \text { 与終了 } \\
1 \text { 週 後 }\end{array}$ \\
\hline I & 子宮癌術後 & (38才) & 29.0 & 38.4 & 20.4 \\
\hline II & 子宮癌術後 & (53才) & 13.1 & 26.1 & 21.5 \\
\hline III & 子宮癌術後 & (62才) & 20.0 & 34.0 & 37.0 \\
\hline IV & 子宮癌術後 & (40才) & 21.8 & 24.4 & 16.4 \\
\hline $\mathrm{V}$ & 子宮癌術後 & (30才) & 10.8 & 14.6 & 16.2 \\
\hline VI & 更年期障碍 & (52才) & 13.0 & 15.4 & / \\
\hline VII & 更年期障碍 & (48才) & 18.8 & 19.4 & 1 \\
\hline
\end{tabular}

第 5 図 腔脂高角化指数の推移

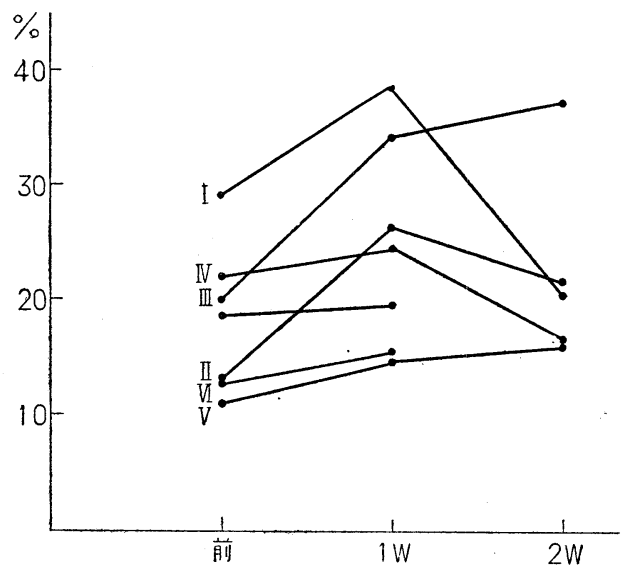

加するのは当然のととであるが，同時に Estradiol, Estrone の両分画が共に增すも のの多いととは注目すべき所見と云える。

今回の実験刘象は去梦婦人であるから，尿 中に検出されるこれら二つの biologically active estrogene は共㣂副皮質由来のもの と考えてよく, 従つて, Estriol 投与後にこ の分画が増すととは， Estriol を投与すると 他の二つの active estrogene から Estriolへ の転換が多少とも遅延するのではないか，従 つて Estriol 投与後には生体内では Estrone Estradiolが蓄積されるのではないかと考える 人もあるが，反面 Estriol が何等かの機序に より副腎からのてれらの Steroid の分泌を 促進すると考えるのも早計ではないと思う。

Estriol 投与後には，17-Ketosteroid も增 
しているのであるから，てれと上記副腎由来 の Estrogene の増加とを併せ考壳るならば， Estriol が副㹂皮質でのてれら Steroid の分 泌を充進せしめ, 更に進んで皮質機能に対 し，促進的作用すると考光てさしつか党な いと思われる。

今日 Estrogene が副腎皮質に対し，機能 促進的作用するととは一般認められてお り，その作用機序に関しては大略次の $3 つ の$ 可能性が考えられる.

1. Estrogene が間脳を介し, 下垂体前葉 よりの AGTH 分泌を直接的に促進せしぬ, その結果二次的漂腎皮質を刺㦸する。

2. Estrogene が下垂体前葉よりの Gonadotropin 分泌を抑制する結果, 前葉の機能 亿所謂 stress shift の現象 $\left(\right.$ Selye $\left.{ }^{10}\right)$ がお こり, その結果 AGTH の分泌が意起され $\tau$, (Sekretions-umstellung, Tonutti ${ }^{11)}$ ) $\tau$ れが二次的に副梷皮質を刺軲する。

3. Estrogene が直接副腎代対し促進的作 用を発揮する。

てれらの生物学的反応はすべて動物実験に より証明された事実である.

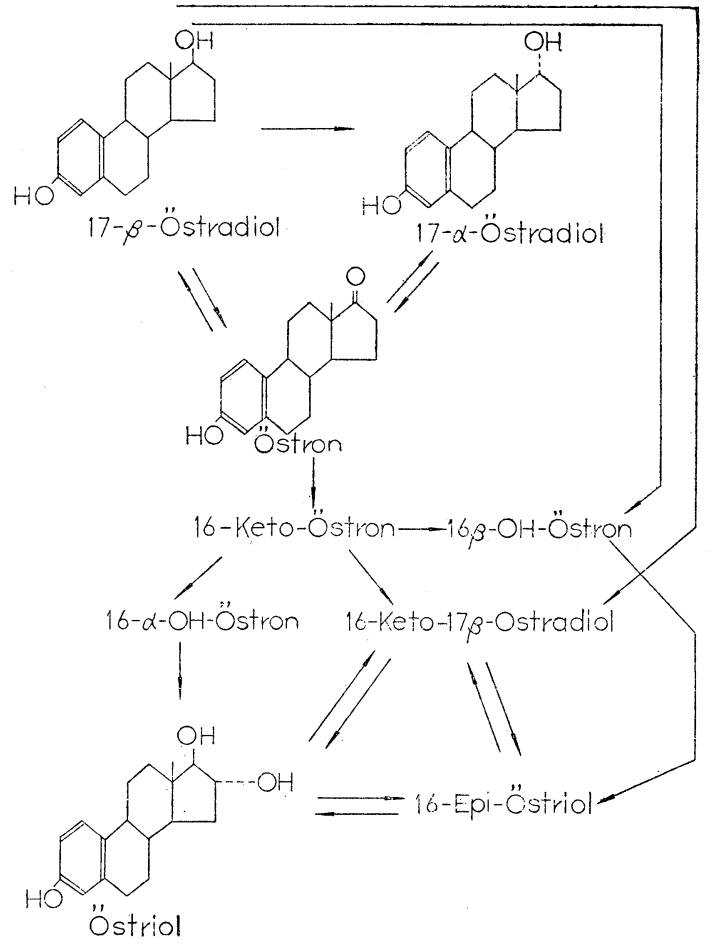

[Schnitte]

一方，尿中 17-Ketosteroid の増加，副粲由来の Estrogene の增加の原因となる tropic hormone につい ても，大略二つの意見が対立している.

その一つは ACTH がてれらの性ステロイドの増加に関与するとする説であり，一方副腎由来の性ステロ イドの増加は Gonadotropin の副腎皮質に対する直接作用によるものであるとの説もある. (Botella ${ }^{12}$ )

著者等の実験成績からすれば，尿中 Gonadotropin の減少しているのにもかかわらず，副腎皮質由来の 17-Ketosteroid, Estradiol, Estrone などがむしろ増加しているのであるからして, Estriol の作用機序に関 する限り, Botella 等の見解には組し難い.

とも角, 前述の 3 つの中のどの経路をたどるにせよ，Estriol が副腎皮質機能に対し，或る程度促進的に 作用しているのは事実の様である.

てのように Estriol は下垂体前葉よりの Gonadotropin 分泌を抑制する作用と共に，副㹂皮質を刺㦸す る作用があるようであり，乙のととを，第 1 報で述べた更年期障碍，月経前緊張症，月経困難症等の成因に 関する諸家の見解と照合すると，上述の成績は，乙れら症候群の成立機序，治療機転の解明に一つの光明を 与えるものではなからうかと考える。例えば更年期障碍の成因としては「性腺機能の老化伴う Gonhdotropin 分泌過剩」説が有力であるし，また本症候群のあるものでは副腎機能の低下が有力な発症原因となつ ているようであるから， Estriol によりてのような Hormone milieu の不均衡が是正され得るとすれば， Estriol の生物学的意義は甚だ大きいと云うととが出来るわけである.

最後に Estriol 投与後に角化指数が增加したととは, Puck 等が云うように Estriol が, 所謂 “Estrogene of Vagina”として㓐粘膜に対して直接的に作用した結果と一応考元られるけれぞも，前述のように，Estriol 投与終了直後には Estradiol, Estrone 等も増すものが多いようであるから，てれらの “biologically active 
estrogene"の協同作用を無視するととは出来ないと思う．

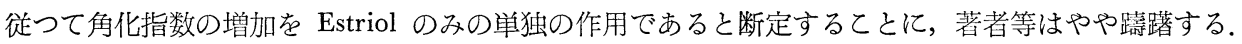

結語

去勢婦人に Estriol を投与し，尿中諸種ホルモンの系統的検索を行つたとてろ, Gonadotropin の減少と， Estradiol，Estrone，Estriol 三分画の增加，17-Ketosteroid の增加を認め，Estriol 飞下垂体前葉よりの Gonadotropin 分泌を抑制する作用と，副警皮犋機能を促進する作用があるととを推定した． また Estriol 投与により胠脂亭の角化指数はすべて增加した。

終りに臨み，御校閲を睗わつた恩師三林教授に深謝します。本研究に試供品走提供下さいました持田製 薬に謝意を捧げます。

\section{参 考 文 献}

1) Puck, A. : Münch. med. Wschr., $99: 1$, Oct. 1957. Puck, A. : Arch, Gyn. Münch., 189 : 278, 1957.

2) Hübner : Zbl Gyn., $81: 914,1959 . \quad 3$ 3) Borglin : Act. Obst. et Gyn. Scandinav., $38: 157,1959$.

4) 東条伸平, 真鍋幸夫, 三木通三 : 日内分泌誌，36；11，1961. 5 5) Hohlweg : Zbl. f. Gyn., Heft

4, 330. $1949 . \quad$ 6) Schnitte : Biochem. J., 71, 26, $1959 . \quad$ 7) Moord \&Price : Proc. soc. exp.

Biol. Med., 28, 38, $1930 . \quad$ 8) Meyer et al. : a) Proc. Soc. Exp. Biol. Med., 27, 702, 1930. b)

Endocrinology. 16, 655, 1932.

9) Frankle \& Salmon : Proc. Soc. Med., $34:$ 463, 1936.

10)

Selye : 沉適応症候群 (田多井吉之助) より引用. 11) Tonutti. : Zschr. mikrosk. anat. Forsch., 51,

346. 1942.112$)$ Borella : Arch. f. Gyn., $183: 73,1953$.

1，1958. 14）谷 明夫：産婦の進歩， $12: 4,99,1960$.

$8: 4,15,1960$, 同 $: 8: 6,29,1960$.
13）大橋，東条：日独医報，3，3，

15）志田圭三他：「木」と臨, 